\title{
Antibacterial Activity of Essential Oil from Rosemytle Leaves (Rhodomyrtus tomentosa (Ait.) Hassk)
}

\author{
Salni,*, and Hanifa Marisa \\ Department of Biology, Faculty of Mathematics and Natural Science, Universitas Sriwijaya \\ *Corresponding author email: salnibasir@unsri.ac.id
}

Received November 09, 2019; Accepted July 04, 2020; Available online November 20, 2020

\begin{abstract}
Rosemytle leaves (Rhodomyrtus tomentosa (Ait.) Hassk) have been used by society to treat various diseases related to bacterial infections, such as dysentery and typhoid fever caused by Shigella dysenteriae and Salmonella typhi, respectively. This study aimed to evaluate the antibacterial activity of essential oils from rosemytle leaves against both bacterias. Extraction was performed with a macerating device using $n$-hexane, ethyl acetate, and ethanol extracts, sequentially. This study used the agar diffusion method to test the antibacterial activity applied to the essential oils with concentrations of $1000,500,250,125,62.5$, and $31.25 \mu \mathrm{g} / \mathrm{mL}$. The antibacterial test results showed that $n$-hexane and ethyl acetate extracts were active against both bacterias while ethanol extract was not. Then, isolates N1 and E1 were produced respectively from $n$-hexane extract and ethyl acetate extract. The MIC values of both N1 and El for S. dysenteriae, and S. typhi were the same, namely $125 \mu \mathrm{g} / \mathrm{mL}$. Isolate $\mathrm{N} 1$ was an essential oil containing menthol (59.60\%), caryophyllene $(25.77 \%)$, and cubenol (14.63\%) while isolate El was an essential oil containing (73.93\%), pentanone $(8.30 \%)$, alpha calacorene $(7.58 \%)$, and calacorene (3.78\%). Rosemytle leaves have the potential to be developed as a drug to treat dysentery and typhoid fever.
\end{abstract}

Keywords: Rosemytle, Rhodomyrtus tomentosa, S. dysenteriae, S. typhi

\section{INTRODUCTION}

Nature provides raw materials for both traditional and modern medicines. The presence of various plants that support life has led researchers to discover their benefits to treat certain infectious diseases. WHO reported that $80 \%$ of the world population had been using conventional medicines, which are mostly plant-based, to care for their health (Kamazeri, 2012).

Plants utilize essential oils they contain to protect themselves against bacteria, viruses, fungi, and pests. People in the Middle Ages used these oils for preservative and flavoring, antibacterial, antifungal, analgesic, sedative, anti-inflammatory, spasmolytic, and local-anesthetic drugs. Currently, around 3,000 kinds of essential oils have been discovered, 300 of which are utilized for commercial use in various industries, such as pharmacy, agronomy, food, tourism, cosmetics, and perfume (Saranraj \& Devi, 2017). In plants, the oils are found in leaves, fruits, flowers, stems, and roots of the families Myrtaceae, Asteraceae, Aristolochiaceae, Lamiaceae, Cupressaceae, Fabaceae, Lauraceae, Meliaceae, and Rutaceae (Shah, Jani, Shah, Chaudhary, \& Shah, 2014; Raut, Sawant, \& Jamge, 2014).

Found in Southeast Asia, Rhodomyrtus tomentosa (Ait.) Hassk, so-called rosemytle, comes from the family Myrtaceae. People use its roots, leaves, and fruits for conventional medicine. Extracts from the aerial part of rosemyrtle contain different bioactive phytochemicals and have been found to have antibacterial, antifungal, anti-inflammatory, antimalarial, antioxidant, and osteogenic activities (Hazrulrizawati \& Zeyohannes, 2017).

Salni and Marisa (2019) found that $n$-hexane and ethyl acetate extracts from rosemytle were active against $S$. typhi and $S$. dysentriae bacteria, with MIC values of of $250 \mu \mathrm{g} / \mathrm{mL}$. Rosemytle leaves contain rhodomyrtone, a natural antibiotic or antibacterial compound that is derived from phloroglucinol (Dachriyanus et al., 2002), that is used for treating staphylococcal skin infections. It has a strong in vitro activity against various grampositive and gram-negative bacterias. With ethanol extracted from the same origin, it has a strong antibacterial activity against gram-positive bacterias, including B. cereus, B. subtilis, E. faecalis, $S$. aureus, $S$. pyogenes, and S. salivarius (Limsuwan et al., 2009). Ethanol extract from rosemytle leaves is active against staphylococcal bacteria isolated from acne. Both substances are active against acnecausing bacteria Propionibacterium acnes. Since rhodomyrtone shows very low toxicity to skin cells, ethanol extract from rosemytle can be a candidate for a treating agent for acne (Saising \& Vorayutthikunchai, 2012). 


\section{EXPERIMENTAL SECTION \\ Materials and Tools}

Rosemytle (Rhodomyrtus tomentosa (Ait) Hassk) leaves were collected at Sungayang, Solok. S. dysenteriae and $S$. typhi were obtained from Biopharma, Bandung. The materials prepared were $n$-hexane, ethyl acetate, ethanol, dimethyl sulfoxide (DMSO) solvent, filter paper, disc paper of $6 \mathrm{~mm}$, nutrient agar (NA), medium nutrient broth (NB), and silica gel GF254.

The apparatus used in this experiment were autoclaves, hot plates, incubators, thin layer chromatography, column chromatography, laminar airflow cabinet, magnetic stirrer, electric heater, water bath, capillary pipette, serological pipette, rotary evaporator, macerating tool, GC-MS, blender, measuring cups, water baths, and petri dishes.

\section{Isolation of Active Compounds}

As much as 100 grams of powdered rosemyrtle leaves were extracted using macerating tools with solvents, started with $1 \mathrm{~L} n$-hexane for $2 \times 24$ hours, ethyl acetate, and ethanol, respectively. Each extract was evaporated in a rotavapor until becoming a paste and then tested for its antibacterial activity. The most active extracts were fractionated using the vacuum liquid chromatograpic method with sloping elvent consisting of $n$-hexane, ethyl acetate, and ethanol in 12 fractions. The fractionation began with non-polar solvents, $100 \% n$-hexane, followed by 12 combinations of solvents in the form of $n$-hexane and ethyl acetate, ethyl acetate and ethanol, and, finally, $100 \%$ ethanol. The fractions were tested for antibacterial activity by the diffusion method. Furthermore, the active fractions were purified using a gravity column containing silica gel with eluent from $n$-hexane and ethyl acetate (9:1).

\section{Bioautography Tests}

To obtain the Rf value of antibacterial compounds, the active fractions were examined using the TLCbioautographic method. An active fraction was loaded onto two TLC plates, which were placed in vessels with a ratio of $n$-hexane and ethyl acetate of $8: 2$. The first chromatogram was placed with a bacterial culture on a petri dish and left attached to the media for 1 hour. The petri dish was then incubated for 24 hours. Bright spots caused by the active compound was observed to calculate the $\mathrm{Rf}$ value. An $\mathrm{H}_{2} \mathrm{SO}_{4}$ solution was sprayed on the second chromatogram. Based on the color formed, the class of active compounds can be estimated: yellow for phenols, purple for terpenoids, and brown for tannin groups (Farnsworth, 1996).

\section{Antibacterial activity test}

n-hexane extract, ethyl acetate extract, and ethanol extract from leaves of Rhodomyrtus tomentosa were tested for their ability to inhibit the growth of $S$. dysenteriae, and S. typhi bacteria. Antibacterial activity tests were carried out on paper discs using the agar diffusion method by placing 50 $\mu \mathrm{L}$ of bacterial suspension into $10 \mathrm{~mL}$ of each medium that had previously been diluted in a petri dish. The media were then allowed to become stable. Paper discs with a diameter of $6 \mathrm{~mm}$ were placed on the surfaces of reliable media. A total of $20 \mu \mathrm{L}$ of the tested mixture was dropped on each disc and allowed to spread for 30 minutes. Then, the discs were placed in an incubator with a temperature of $37^{\circ} \mathrm{C}$. MIC was determined using the diffusion method with various concentrations of active compounds of 1000,500, 250, 125, 62.5, and $31.25 \mu \mathrm{g} / \mathrm{mL}$. The solvent used to dissolve isolates $\mathrm{N} 1$ and $\mathrm{E} 1$ was dimethylsulfoxide.

\section{RESULT AND DISCUSSION Isolation of Active Compounds}

The test results of antibacterial activity against bacterias causing dysentery and typhoid fever, namely $S$. dysenteriae and S. typhi, respectively, using $n$-hexane, ethyl acetate, and ethanol extracts indicated that only $n$-hexane and ethyl acetate extracts were active against bacteria, while ethanol extract was not. Both extracts were fractionated by the vacuum liquid chromatography method with eluent level consisting of $n$-hexane, ethyl acetate, and ethanol extracts. The results of the antibacterial activity test of $n$-hexane extract showed that the active fractions were fraction $3(\mathrm{HC})$, fraction $6(\mathrm{HG})$, and fraction $7(\mathrm{HI})$. Furthermore, fraction $3(\mathrm{HC})$ was added in the gravity column with eluent $n$-hexane and ethyl acetate with a ratio of $(9: 1)$. Active isolate (isolate N1) was obtained in bottles 6 to 8 , as in Figure 1 (a). The results of the antibacterial activity test of ethyl acetate extract showed that active fractions were found in fractions 2 (EB) to $6(E F)$ and fractions 12 (EL) to $13(E M)$. Fractions $2(E B)$ to $6(E F)$ were applied in a column chromatography containing elvent $n$-hexane and ethyl acetate with a ratio of 9:1. The active fractions were shown in bottles 5 to 9 (E1 isolate), Figure 1(b). Isolates N1 and $E 1$ were obtained in the forms of brownish yellow paste. Bioautography tests were performed on both isolates to determine the Rf values and the classes of their active fractions.

\section{Bioautography Tests}

Bioautography test results showed that isolates $\mathrm{N} 1$ and $E 1$ had Rf values of 0.22 and 0.33 , respectively. After being sprayed with $10 \% \mathrm{H}_{2} \mathrm{SO}_{4}$ solution, both isolates showed purple spots, indicating the existence of terpenoids (essential oils), as shown in Table 1 and Figure 2. The figure also shows the presence of obstacles (bright areas) in bacterial cultures that indicates the inability of bacteria to grow due to the presence of antibacterial compounds.

From the colors, it can be concluded that the active compounds contained by both isolates $\mathrm{N} 1$ and E1 were terpenoids (essential oils). Both isolates were active against $S$. dysenteriae and $S$. typhi that 
respectively cause dysentery and typhoid fever. The antibacterial activity of $n$-hexane and ethyl acetate extracts was expected due to the presence of essential oils from rosemytle leaves, that had never been reported before. Thus, both extracts had the potential as raw materials for drugs to deal with dysentery and typhoid fever.

Essential oils also contain several types of terpenoid compounds. According to the results of previous studies, essential oils consisting of terpenoids showed antibacterial activity. The composition of essential oils can vary in different parts of the same plant. Research by Benchaar et al. (2008) showed that essential oils are mixtures consisting mainly of terpenoids, especially monoterpenes (C10) and sesquiterpenes (C15). However, diterpenes (C20) can also be in the forms of acids, alcohols, aldehydes, acyclic esters or lactones, and extraordinary compounds containing
$\mathrm{N}$ - and S, coumarin, and phenylpropanoid homologs.

Essential oils that are found to have antibacterial activity contain terpenoids. The results of this study are supported by the research of Trombetta et al. (2005), which found three monoterpenes, namely linalyl acetate, menthol, and thymol active against $S$. aureus and E. coli, which are a gram-positive and gram-negative bacterias, respectively. Research on the antibacterial activity of essential oils thymol, carvacrol, eugenol, and menthol on four strains of bacterias that cause nosocomial infections, namely $E$. coli, P.aeruginosa, K. pneumonia, and S. aureus, showed that thymol, carvacrol, and eugenol have significant antibacterial activity. Thymol has a high antibacterial activity against $S$. aureus and $E$. coli with MIC values of $0.35 \mathrm{mg} / \mathrm{mL}$ while menthol has low activity against all bacterias tested with MIC values greater than $6 \mathrm{mg} / \mathrm{mL}$ (Atki et al., 2019).
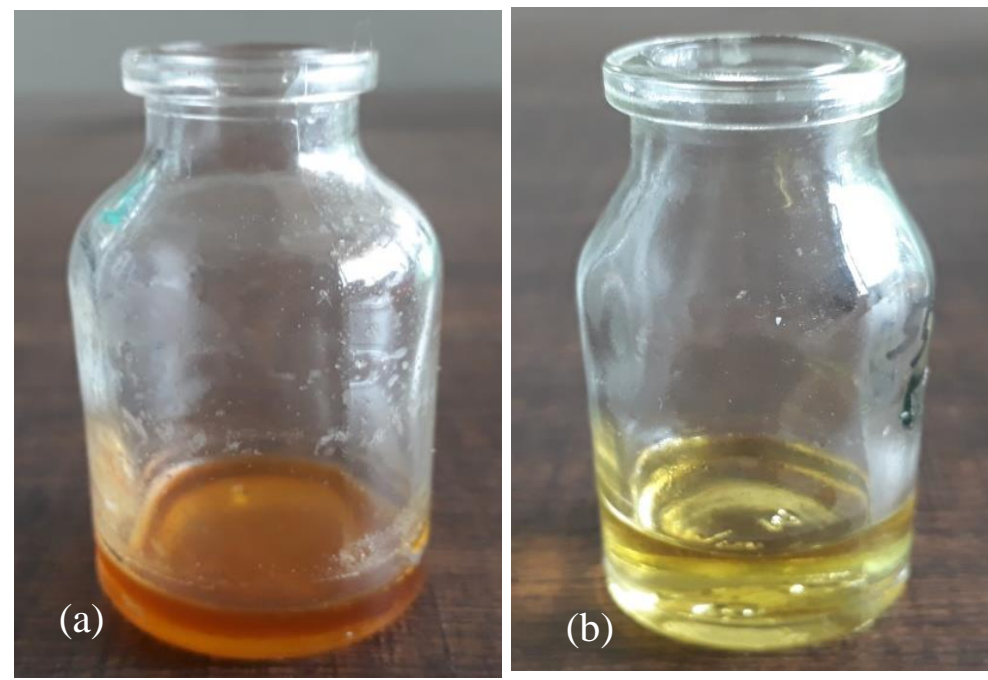

Figure 1. Isolates (a) N1 and (b) E1

Table 1. Rf values and classes of active compounds of isolates $\mathrm{N} 1$ and $\mathrm{E} 1$ from rosemytle leaves.

\begin{tabular}{lcll}
\hline Compound & Rf & Color & Class \\
\hline Isolate N1 & 0.22 & Purple & Terpenoid \\
Isolate E1 & 0.33 & Purple & Terpenoid \\
\hline
\end{tabular}
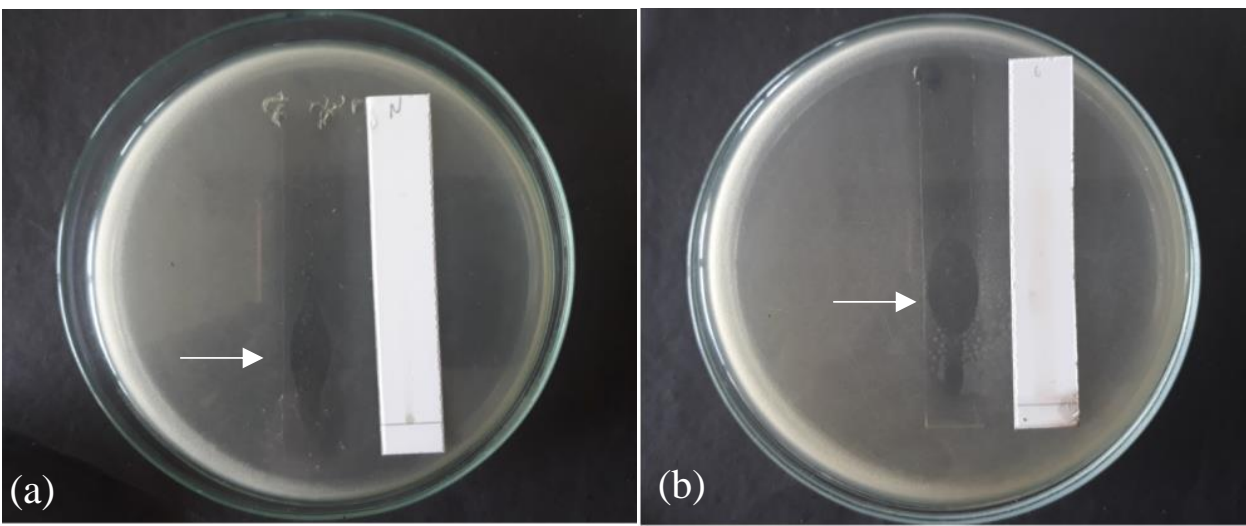

Figure 2. Bioautography test results and determination of active fraction groups of isolates (a) N1 and (b) E1 


\section{Characterization of Isolates $\mathrm{N} 1$ and El}

Characterization of isolate N1 was done using GC-MS. The obtained GC-MS chromatogram is shown in Figure 3. In the figure, there are three dominant peaks identified. The dominant peaks 16.919, 12.621, and 15.236 indicates content percentages of menthol (59.60\%), caryophyllene (25.77\%), and cubenol (14.63\%). The contents of isolate $\mathrm{N} 1$ is shown completely in Table 2.

The essential oils contained by isolate $\mathrm{N} 1$ are menthol, caryophyllene, and cubenol. N1 was active against S. dysenteriae and S. typhi bacterias. Several studies were found some findings related to this research. Peppermint (Mentha piperita L.) was found to contain menthol (20-54\%), 1-menton (15-43\%), mentil acetate (1-29\%), and menthofuran (1-8\%). Various species of mints were also found to have antimicrobial properties against S. aureus, E. faecalis, P. vulgaris, C. perfringens, B. brevis, and V. cholerae. Peppermint oils can be used to treat digestive tracts infected by $S$. enteritidis, S. typhimurium, S. sonnei, L. monocytogenes, and E. coli. These essential oils also showed strong activity in methicillin-resistant strains of $S$. aureus and $H$. pylori genera (Sienkiewicz, Denys, \& Kowalczyk, 2011 ).

A study revealed that essential oils of Mentha rotundifolia consist of, mainly, menthol (40.50\%) and other predominant constituents, namely menthone, menthyl acetate, menthofuran, oxyde de piperitone, linalyl acetate, neomenthol, piperitone, isomenthone, 1,8-cineole, linalool, limonene, geraniol, myrcene, geranyl acetate, and trans sabinene hydrate. The essential oils extracted from Mentha rotundifolia showed the highest activity against E. coli, S. aureus, and S. intermedius, with the most potent inhibitory zones of 45, 34, and 31 $\mathrm{mm}$, respectively (Derwich, Benziane, \& Boukir, 2010).

Isolate El was characterized by GC-MS. The results obtained can be seen in Figure 4. Table 3 shows the essential oils contained by isolate El from the characterization. Isolate El contains, mainly, menthol 73.93\%, pentanone $8,73 \%$, and alpha calacorene $7.58 \%$, Like isolate $\mathrm{N} 1$, the menthol compound also has the highest content percentage in El.

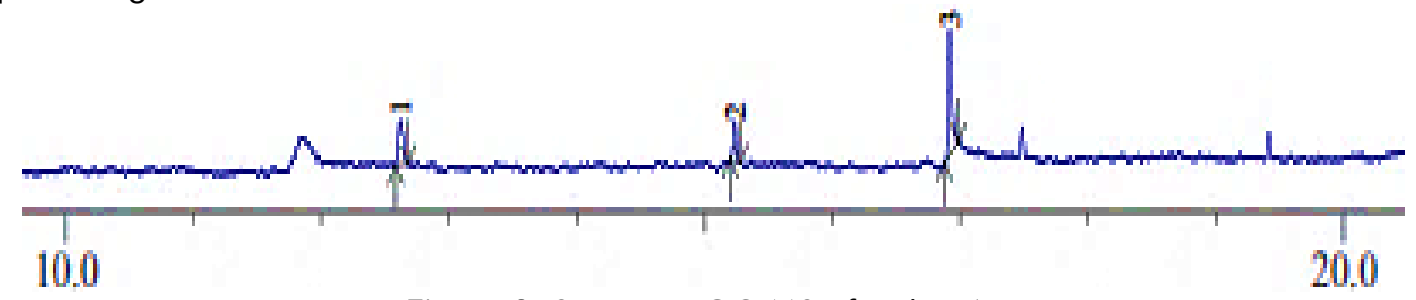

Figure 3. Spectrum GC-MS of isolate N1

Table 2. The essential oils contained by isolate N1

\begin{tabular}{llll}
\hline No. & Peaks & Percentage (\%) & Essential oil \\
\hline 1 & 12.621 & 25.77 & Caryophyllene \\
2 & 15.236 & 14.63 & Cubenol \\
3 & 16.919 & 59.60 & Menthol \\
\hline
\end{tabular}

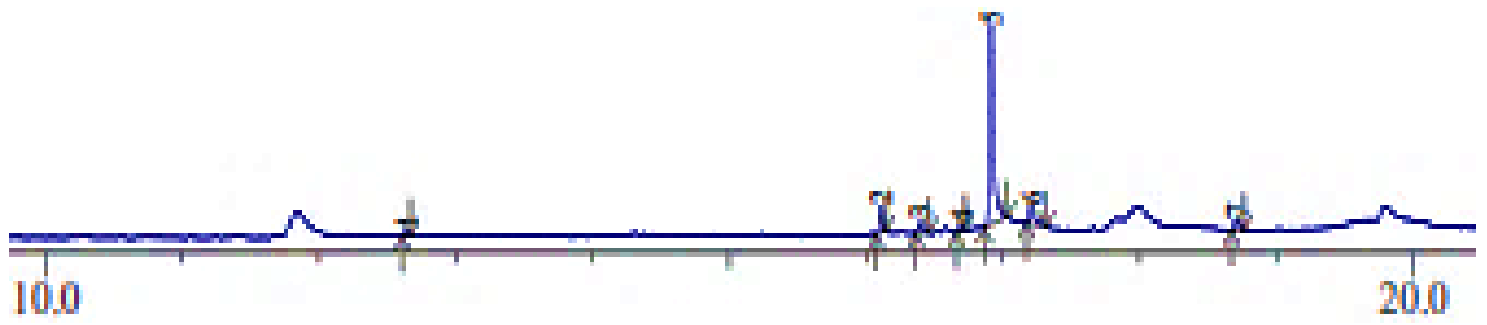

Figure 4. Spectrum of GC-MS of isolate E1

Table 3. The essential oils of isolate E1

\begin{tabular}{llll}
\hline No. & Peaks & Percentage $(\%)$ & Essential oil \\
\hline 1 & 12.642 & 1.16 & Cyclohexene \\
2 & 16.111 & 7.58 & Alpha Calacorene \\
3 & 16.396 & 3.78 & Calacorene \\
4 & 16.701 & 1.49 & Caryophyllene \\
5 & 16.918 & 73.93 & Menthol \\
6 & 17.209 & 8.30 & Pentanone \\
7 & 18.712 & 3.75 & Isopropyl \\
\hline
\end{tabular}


Another previous study also showed contents similar to those of isolates N1 and E1. Salvia triloba in South Brazil has been reported to have essential oils, including 8 -caryophyllene, along with $\alpha$-thujone, 1,8-cineole, and camphor, exhibiting extraordinary bacteriostatic and bactericidal activity against $B$. cereus, B. megatherium, B. subtilis, A. hydrophila, A. sobria, and K. oxytoca (Delamare, Moschen, Atti, \& Echeverrigaray, 2007).

Soetjipto, Dewi \& Prayitno (2008) investigated the chemical contents in antibacterial compounds from Japanese lavender (Tithonia diversifolia (Hemsley) A. Gray) and gave similar results to this study. They showed that the essential oils contained 29 components consisting of, mainly, caryophyllene $(27.76 \%)$, nerolidol (21.81\%), caryophyllene oxide $(7.06 \%)$, copaene $(6.41 \%)$ and bicylogermacrene (4.90\%). To determine the antibacterial activity, a bioautography test was performed. Bioautography test results of two antibacterial spots gave Rf values of 0.49 and 0.61 . The spots with an Rf value of 0.49 were a mixture of 21 compounds with henisicon, nonacosana, and tetratetracontane as the main compounds, while spots with an Rf value of 0.61 consist of 22 compounds with nerolidol as the main compound.

The characterization results showed that $\mathrm{N} 1$ and El contain several compounds following research conducted on essential oils from 10 commonly consumed herbs. The main components of these essential oils are camphor, carvacrol, 1,8-cineole, linalool, linalyl acetate, limonene, menthol, a-inene, b-pinene, and thymol. The essential oils have antibacterial activity against human pathogenic bacterias, namely B. subtilis, E. cloacae, E. coli, M. flavus, $P$. mirabilis, $P$. aeruginosa, $S$. enteritidis, $S$. epidermidis, $S$. typhimurium, and. aureus. The highest and fullest activity was shown by Origanum vulgare oil. Carvacrol had the highest antibacterial activity among the components tested (Sokovic, Glamočlija, Marin, Brkić, \& Griensven, 2010).

\section{Minimum Inhibitory Concentration (MIC) of The Isolates}

From the results of the isolation of the antibacterial compounds, the active compounds of isolate N1 were obtained from $n$-hexane extract, whereas, the active compounds of isolate El were obtained from ethyl acetate extract. Both N1 and El were essential oils. The results of determining the MIC value of isolate N1 can be seen in Table 4 and Figure 5. The following shows the MIC value of isolate $\mathrm{E} 1$ in Table 5 and Figure 6.

As shown in Table 4, isolate N1 at a concentration of $1000 \mu \mathrm{g} / \mathrm{mL}$ produced the largest inhibitory diameters of $19.33 \mathrm{~mm}$ for $S$. dysenteries and $18.33 \mathrm{~mm}$ for $S$. typhi. The test results in table 4 also show that the decrease in isolate $\mathrm{N} 1$ concentration resulted in smaller inhibitory diameter. The smallest inhibition against $S$. dysenteriae and $S$. typhi was obtained at a concentration of $125 \mu \mathrm{g} / \mathrm{mL}$, meaning that the MIC value of isolate $\mathrm{N} 1$ was $125 \mu \mathrm{g} / \mathrm{mL}$.

Table 4. Antibacterial activity of isolate $N 1$ against $S$. dysenteriae and S. typhi

\begin{tabular}{lccc}
\hline No & $\begin{array}{c}\text { Concentration } \\
\mu \mathrm{g} / \mathrm{mL}\end{array}$ & \multicolumn{2}{c}{ Inhibitory zone diameter $(\mathrm{mm})$} \\
\cline { 3 - 4 } & & S. dysenteriae & S. typhi \\
& & $19.33 \pm 0.57$ & (Mean $\pm \mathrm{SD})$ \\
\hline 1 & 1000 & $17.33 \pm 0.57$ & $13.33 \pm 0.57$ \\
2 & 500 & $12.33 \pm 0.57$ & $10.33 \pm 0.57$ \\
3 & 250 & $9.33 \pm 0.57$ & $8.33 \pm 0.57$ \\
4 & 125 & 0 & 0 \\
5 & 62.5 & 0 & 0 \\
6 & 31.25 & & \\
\hline
\end{tabular}

Table 5. Antibacterial activity of isolate El against $S$. dysenteriae and S. typhi

\begin{tabular}{lccc}
\hline No & $\begin{array}{c}\text { Concentration } \\
\mu \mathrm{g} / \mathrm{mL}\end{array}$ & \multicolumn{2}{c}{ Inhibitory zone diameter $(\mathrm{mm})$} \\
\cline { 3 - 4 } & & S. dysenteriae & S. typhi \\
& & $17.00 \pm 1.00$ & (Mean \pm SD) \\
\hline 1 & 1000 & $11.66 \pm 1.52$ & $16.00 \pm 1.00$ \\
2 & 500 & $10.33 \pm 0.57$ & $9.66 \pm 1.52$ \\
3 & 250 & $9.66 \pm 1.52$ & $8.33 \pm 0.57$ \\
4 & 125 & 0 & 0 \\
5 & 62.5 & 0 & 0 \\
6 & 31.25 & & (Mean \pm \\
\hline
\end{tabular}




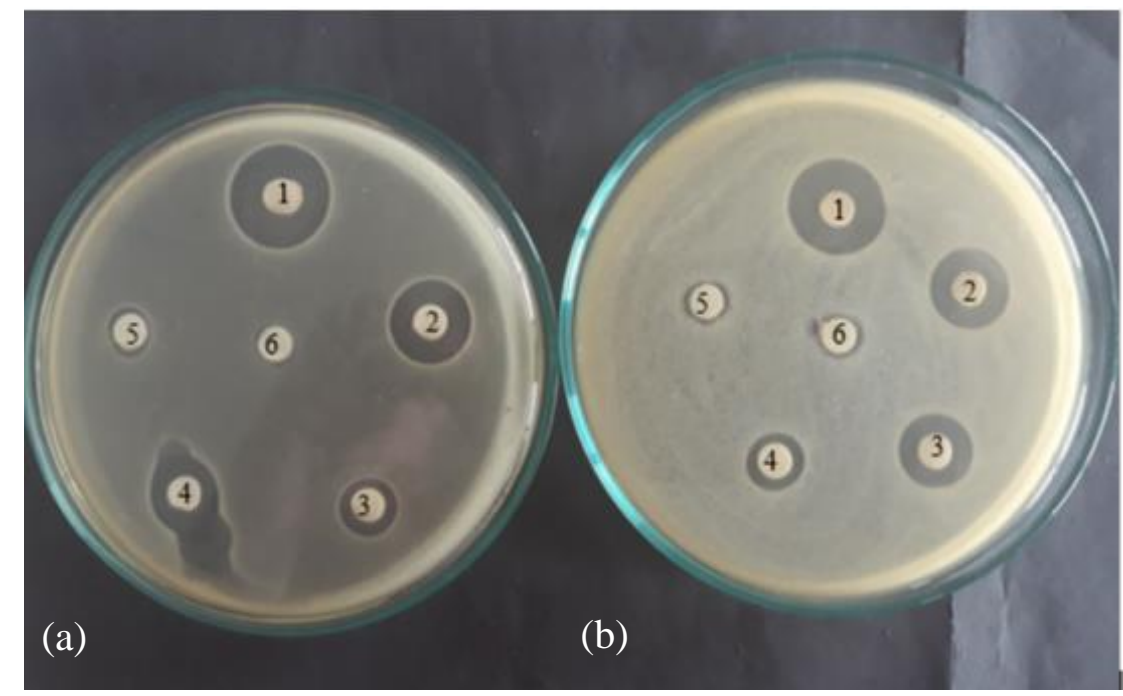

Figure 5. The inhibitory zone of isolate N1 against (a) S. thypi and (b) S. dysentriae bacterias

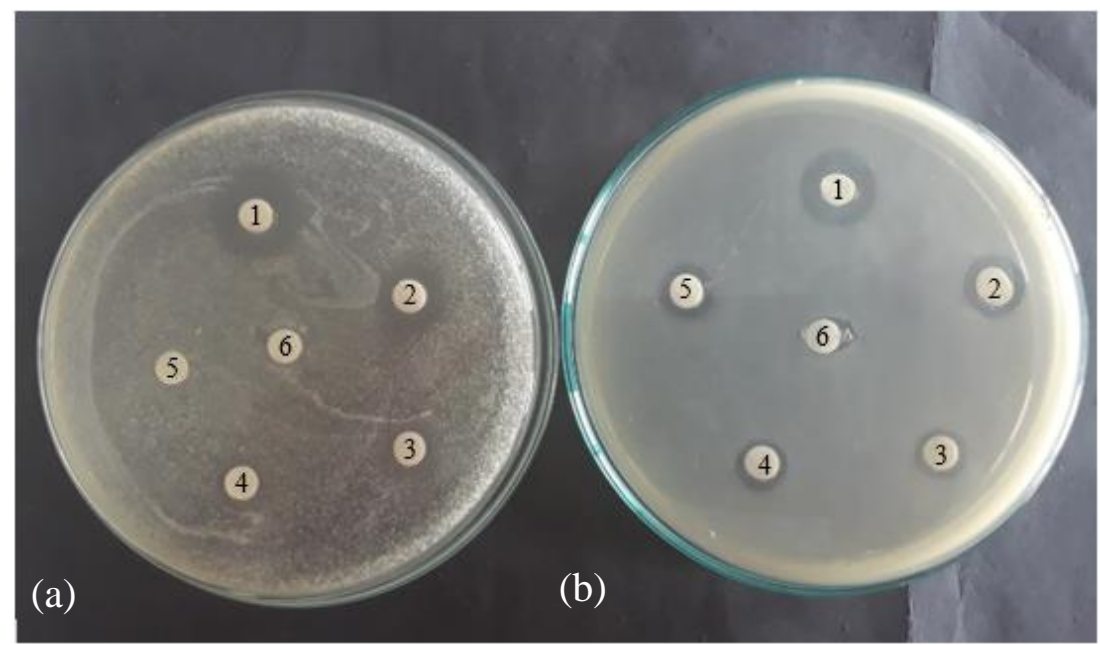

Figure 6. The inhibitory zone of isolate El against (a) S. thypi and (b) S. dysentriae bacterias

The antibacterial activity of isolate E1 showed that the largest inhibitory diameter of bacterial growth was found at a concentration of $1000 \mu \mathrm{g} / \mathrm{mL}$ with inhibitory diameters of $17.00 \mathrm{~mm}$ for S. dysenteriae and $16.00 \mathrm{~mm}$ for S. typhi. The test results also showed that the decreasing concentration of isolate E1 decreases inhibitory diameter produced. The smallest resistance against $S$. dysenteriae and $S$. typhi was obtained at a concentration of $125 \mu \mathrm{g} / \mathrm{mL}$, hence it can be stated that the MIC value of El isolate is $125 \mu \mathrm{g} / \mathrm{mL}$. The MIC values of isolates N1 and $\mathrm{E} 1$ containing menthol against $S$. thypi and $S$. dysenteriae bacteria were $125 \mu \mathrm{g} / \mathrm{mL}$, smaller than $M I C$ values of essential oils thymol against $S$. aureus and E. coli, which were $310 \mu \mathrm{g} / \mathrm{mL}$ and $500 \mu \mathrm{g} / \mathrm{mL}$, respectively. Against the same bacterias, menthol had MIC values of $620 \mathrm{mg} / \mathrm{mL}$ and $250 \mu \mathrm{g} / \mathrm{mL}$, while linalyl acetate had MIC values of $125 \mathrm{mg} / \mathrm{mL}$ and $500 \mu \mathrm{g} / \mathrm{mL}$ (Trombetta et al., 2005).

MIC values of isolates $\mathrm{N} I$ and EI were classified as antibacterial with strong activity. Holetz et al. (2009) classified antibacterial compounds based on their MIC values. Antibacterial compounds with MIC less than $100 \mu \mathrm{g} / \mathrm{mL}$ are classified as very strong. Compounds are classified as strong enough when having MIC values ranging from 100 to $500 \mu \mathrm{g} / \mathrm{mL}$. Whereas, those having MIC values ranging from 500 to $1000 \mu \mathrm{g} / \mathrm{m}$ are classified as weak. Meanwhile, compounds are classified to have no antibacterial activity when having MIC values of more than 1000 $\mu \mathrm{g} / \mathrm{mL}$. Both isolates $\mathrm{N} 1$ and $\mathrm{El}$ isolate have the same MIC value of $125 \mu \mathrm{g} / \mathrm{mL}$, thus categorized as strong enough.

MIC values of isolates $\mathrm{N} 1$ and $\mathrm{El}$ against both bacterias were $125 \mu \mathrm{g} / \mathrm{mL}$, which are the same as that of fennel (Foeniculum vulgare Mill.) showed by the investigation by Diao, Hua, Zhanga, \& Xuab (2014), which also revealed that MIC values of essential oils from fennel showed the antibacterial activity against $S$. typhimurium, $S$. dysenteriae and $E$. coli. These essential oils showed the most active reaction to $S$. dysenteriae when reaching the lowest MIC value of $125 \mu \mathrm{g} / \mathrm{mL}$. Besides, the killing time test also showed that the essential oils of fennel were the 
fastest in killing $S$. dysenteriae. Based on the results of tests and observations of using electron microscope, the essential oils worked against $S$. dysenteriae on its membrane integrity and caused its electrolyte leakage and loss of contents (protein, sugars, and materials sized $260 \mathrm{~nm}$ ).

The mechanism of antibacterial action is carried out by three monoterpenes, namely menthol, thymol, and linalyl acetate by causing interference with the plasma membrane lipids of microorganisms that result in changes in cell membrane permeability. This effect depends on the lipid content and the surface charge of the microbial cell membrane. Changes in permeability cause drug ingredients to cross the cell membrane, penetrate the interior of the cell, and interact with intracellular material that is important for antibacterial activity (Trombetta et al., 2005).

The main components of essential oils N1 and E1 are the same as those found in peppermint oil. Peppermint oil with antiseptic properties derived from the family Labiatae has antibacterial activity. The MIC values of peppermint oil for various types of microorganisms are in the range of $0.125-2 \mu \mathrm{L} / \mathrm{mL}$. Candida albicans is the most sensitive microorganism, and Pseudomonas aeruginosa is the least sensitive. Peppermint oil shows the same activity as vancomycin, gentamicin, and amphotericin B. It can be used as a natural antibiotic and can reduce the dose of an effective antibiotic. Menthol, menthone, and methyl acetate are the main components of peppermint oil, followed by carveone, neomenthol, 1,8-cineole, and limonene (Mahboubi \& Kazempour, 2014).

\section{CONCLUSIONS}

This study aimed to evaluate essential oils derived from Rhodomyrtus tomentosa leaves. Two isolates were obtained from extracts, namely, N1 from nhexane extract and El from ethyl acetate extract. The minimum inhibitory concentration values of $\mathrm{N} 1$ and El against $S$. dysenteriae and $S$. typhi bacterias were the same, namely $125 \mu \mathrm{g} / \mathrm{mL}$. N1 is an essential oil containing, mainly, menthol (59.60\%), caryophyllene (25.77\%), and cyclopentasiloxane (14.63\%) while E1, which is also an essential oil, contains, mainly, menthol (73.93\%), pentanone (8.30\%), alpha calacorene (7.58\%), and calacorene (3.78\%). Rosemytle leaves have the potential to be developed as a medicine for treating patients with dysentery and typhus.

\section{ACKNOWLEDGMENTS}

This study was funded by the grant provided for "Penelitian Terapan Unggulan Perguruan Tinggi" of 2019. The authors would like to express gratitude to the Indonesian Ministry of Higher Education Research and Technology for funding and Universitas Sriwijaya University for permitting the authors to use research facilities in its laboratory.

\section{REFERENCES}

Atki Y. E., Aouam. I., El Kamari, F., Taroq, A., Gourch, A., Lyoussi, B., \& Abdelfattah. (2019). Antibacterial efficacy of thy $5 \mathrm{~mol}$, carvacrol, eugenol, and menthol as alternative agents to control the growth of nosocomial infection-bacteria. Journal of Pharmaceutical Science and Research, 11 (2), 306-309.

Benchaar, C.S., Calsamiglia, A.V., Chaves, G. R., Fraser, D., Colombatto, T.A., McAllister \& Beauchemin K. A. (2008). A review of plantderived essential oils in ruminant nutrition and production. Animal Feed Sciences and Technology, 145(1-4), 209-228.

Dachriyanus, Salni., Sargent, M. V., Skelton B. W., Soediro,I., Sutisna,M., White A. H. \& Yulinah E. (2002). Rhodomyrtone, an antibiotic from Rhodomyrtus tomentosa. Australian Journal of Chemistry, 55(3), 229-232.

Delamare, A. P. L., Moschen I. T., Atti. P. L. \& Echeverrigaray. S. S. (2007). Antibacterial activity of the essential oils of Salvia officinalis L. and Salvia triloba L. cultivated in South Brazil. Food Chemistry, 100(2), 603-608.

Derwich, E., Benziane, Z., \& Boukir, A. (2010). Antibacterial activity and chemical composition of the leaf essential oil of Mentha rotundifolia from Morocco. Electronic Journal of Environmental, Agricultural \& Food Chemistry. 9(1), 19-28.

Diao, W. R., Hua, Q. A. P., Zhanga H \& Xuab J. G. (2014). Chemical composition, antibacterial activity and mechanism of action of essential oil from seeds of fennel (Foeniculum vulgare Mill.), Food Control, 35(1), 109-116.

Farnsworth, N. R. 1966. Biological and phytochemical screening of plants. Journal of Pharmaceutical Sciences. 55, 225-236.

Hazrulrizawati, H., \& Zeyohannes, S. S. (2017). Rhodomyrtus tomentosa: a phytochemical and pharmacologicall review. Asian Journal of Pharmaceutical and Clinical Research, 10, 1-7.

Holetz, F. B., Pessini, G. L., Sanches, N. R., Cortez, D. A. G., Nakamura, C. V., \& Filho B. P. D. (2009). Screening of some plants used in the Brazilian folk medicine for the treatment of infectious diseases. Memórias do Instituto Oswaldo Cruz, 97, 1027-1031.

Kamazeri, T.S. (2012). Antimicrobial activity and essential oils of Curcuma aeruginosa, Curcuma mangga, and Zingiber cassumunar from Malaysia. Asian Pacific Journal of Tropical Medicine, 5(3), 202-209.

Limsuwan, S., Trip, E. N., Kouwen, T. R., Piersma, S., Hiranrat, A., Mahabusarakam, W, Voravuthikunchai, S. P, Van Diil, J. M., \& Kayser, O. (2009). Rhodomyrtone: a new candidate as natural antibacterial drug from 
Rhodomyrtus tomentosa. Phytomedicine, 16(6), 645-651.

Mahboubi, M., \& Kazempour, N. (2014). Chemical composition and antimicrobial activity of peppermint (Mentha piperita L.) essential oil. Songklanakarin Journal of Science and Technology, 36(1), 83-87.

Raut, R. R., Sawant, A. R., \& Jamge, B. B. (2014). Antimicrobial activity of Azadirachta indica (Neem) against pathogenic microorganisms, Journal of Academia and Industrial Research, 3(7), 327-329.

Saising J, \& Vorayutthikunchai SP. (2012). Anti Propionibacterium acnes activity of rhodomyrtone, an effective compound from Rhodomyrtus tomentosa (Aiton) Hassk. leaves. Anaerobe, 18(4), 400-404.

Salni \& Marisa, H. (2019). Evaluation on antibacterial activity of rosemytle leaf extract (Rhodomyrtus tomentosa (Ait) Hassk) with various solvents to $S$. dysenteriae and S. typhi. Malaysian Journal of Fundamental \& Applied Sciences, 15(5), 671-674.

Saranrai, P., \& Devi, V.D. (2017). Essential oils and its antibacterial properties - A review. Life Sciences Archives, 8(2), 994-1011.
Shah, A., Jani, M., Shah, H., Chaudhary, N., \& Shah, A. (2014). Antimicrobial effect of clove oil (Laung) extract on Enterococcus faecalis. Journal of Advanced Oral Research, 5(3), 1-3.

Sienkiewicz, M. Denys, P., \& Kowalczyk., E, 2011 Antibacterial and immunostimulatory effect of essential oil. International Review of Allergology and Clinical Immunology, 17(1-2).

Soetjipto, H., Dewi, E., \& Prayitno.S.A. (2008). Isolasi dan identifikasi senyawa antibakteri minyak atsiri daun kembang bulan \{Tithonia diversifolia (Hemsley) A. Gray\} 1. Berita Biologi, 9(2), 130-139.

Soković, M., Glamočlija, J., Marin, P.D., Brkić, D., \& Griensven L. D.. 2010. Antibacterial Effects of the essential oils of commonly consumed medicinal herbs using an in vitro model. Journal Molecules., 15(11) 732-7546

Trombetta, D, Castelli, F., Sarpietro, M.G., Venuti, V., Cristani, M., Daniele, C., Saija.A, Mazzanti.G., \& Bisignano, G. 2005. Mechanisms of antibacterial action of three monoterpenes. Antimicrobial Agent and Chemotherapy. 49(6): 2474-2478. 